\title{
Bronchoalveolar lavage (BAL) in tapirs (Tapirus terrestris) with Mycobacterium tuberculosis
}

\author{
[Lavado broncoalveolar (LBA) em antas (Tapirus terrestris) com \\ Mycobacterium tuberculosis] \\ J.S. Biava ${ }^{1}$, R.C. Gonçalves ${ }^{1}$, M.L. Javorouski ${ }^{2}$, M. Bonat ${ }^{3}$, O. Lacerda ${ }^{2}$, \\ P.S. Murakami ${ }^{3}$, R.G.D.C. Vilani $^{3}$, A.W. Biondo ${ }^{3}$ \\ ${ }^{1}$ Faculdade de Medicina Veterinária e Zootecnia - Universidade Estadual Paulista - Botucatu, SP \\ ${ }^{2}$ Zoológico Municipal de Curitiba - Curitiba, PR \\ ${ }^{3}$ Universidade Federal do Paraná - Curitiba, PR
}

\begin{abstract}
This paper describes the in vivo Bronchoalveolar lavage (BAL) technique by endoscopy in tapirs (Tapirus terrestris) with clinical signs of tuberculosis. The technique was performed in two tapirs, male and female, from Curitiba Zoo, Paraná, Brazil. A flexible endoscope and a polyethylene catheter were used after the chemical restraint of the animals. For BAL technique, $60 \mathrm{~mL}$ of saline $0.9 \%$ were infused with a polyethylene catheter, introduced by the endoscope's working channel, and $15 \mathrm{~mL}$ of BAL were recovered, analyzed and submitted to cytocentrifugation. Slides were stained by Papanicolaou, periodic acid-Schiff (PAS) and Ziehl-Neelsen methods contained high quantity of inflammatory cells on light microscopy (macrophages $27.5 \%$, lymphocytes $0.5 \%$, neutrophis $67 \%$ and eosinophis $5 \%$ ). BAL samples were submitted to culture, bacilloscopy and PCR and were negative for both animals. Based on this study, it was concluded that the bronchoalveolar lavage technique in tapirs is feasible, simple, noninvasive, practical and fast, providing an important clinical information in vivo regarding the functional status of the lower respiratory tract.
\end{abstract}

Keywords: tapirs, diagnosis, endoscopy, tuberculosis

\section{RESUMO}

O presente trabalho descreve a técnica de lavado broncoalveolar (LBA) por endoscopia em antas (Tapirus terrestris) in vivo com sinais clínicos de tuberculose. A técnica foi realizada em duas antas, um macho e uma fêmea, provenientes do Zoológico de Curitiba, Paraná, Brasil, utilizando-se endoscópio flexível e sonda de polietileno, após a contenção química desses animais. Para o LBA, 60mL de solução fisiológica $0,9 \%$ foram infundidos com auxílio de cateter de polietileno, introduzido pelo canal de trabalho do endoscópio, e, aproximadamente, $15 \mathrm{~mL}$ de LBA foram recuperados, acondicionados, analisados e submetidos à citocentrifugação. As lâminas foram coradas pelas técnicas de Papanicolau, ácido periódico de Schiff (PAS) e Ziehl- Neelsen, método que contém altas quantidades de células inflamatórias em microscopia (macrófagos 27,5\%, linfócitos 0,5\%, neutrófilos 67\% e eosinófilos 5\%). Amostras de LBA foram submetidas a cultura, baciloscopia e PCR e foram negativas em ambos os animais. Concluiu-se, baseado no presente trabalho, que técnica de lavado broncoalveolar é simples, não invasiva, funcional e rápida. Pode fornecer ao clínico importantes informações acerca do estado de funcionamento do aparelho respiratório in vivo.

Palavras-chave: antas, diagnóstico, endoscopia, tuberculose

Recebido em 18 de junho de 2013

Aceito em 4 de agosto de 2014

E-mail: jsbiava@yahoo.com.br 


\section{INTRODUCTION}

Diseases affecting wild animals are not clearly defined and there is little information about the biology and mediane of tapir (Tapirus terrestris) available and limited to some reports of eventual cases (Hernández-Divers et al., 2007). Diagnosis may be difficult in undomesticated animals as there is no standard protocol for these species. Moreover, diagnosis in some wild species may not be efficient when traditional methods are utilized (Murakami et al., 2007). The major diagnostic of pulmonary disease in wildlife animals may be restricted to post-mortem findings, particularly due to tuberculosis (Espie et al., 2009). Tuberculosis has been defined as a disease caused by members of Mycobacterium tuberculosis complex, which consist of $M$. tuberculosis, M. bovis, M. africanum, M. microti, and M. canettii (Michel et al., 2003; Murakami et al., 2012). Animals with tuberculosis most often live in close contact with humans or domesticated animals, and may be a source of tuberculosis (Murakami et al., 2007; Murakami et al., 2012). In a country where M. tuberculosis is frequently isolated from animals, and where legislation requires such drastic measures of suspect animals, the diagnosis is extremely necessary (Sternberg et al., 2002). The clinical signs vary from non-specific signs to fast breathing, respiratory dyspnea and presence of granulomatous injuries (Murakami et al., 2007; Murakami et al., 2012). However, bronchoalveolar lavage (BAL) is beneficial for the diagnosis of both non infectious and infectious respiratory diseases, particularly in interstitial or alveolar pulmonary affections (Biava et al., 2006; Murakami et al., 2012). When combined with endoscopic examination, it provides a good visual assessment of the airways (Andreasen, 2003; Biava et al., 2007). BAL samples may not be suitable for bacterial culture because the polyethylene endoscope or catheter must pass through the nasopharynx before entering in the distal airways, which may give false results (Biava et al., 2006). However, there is a positive correlation between BAL and lung histopathological according to De Brauwer et al. (2000). To perform the bronchoalveolar lavage, a flexible tube through the working channel of the endoscope may be used, or a silicone catheter can be inserted in the bronchi, where aliquots of isotonic fluid can be infused by the light of the tube and recovered manually with $60 \mathrm{~mL}$ syringes
(Biava et al., 2007), carefully avoiding exacerbated negative pressure which may result in less recovered volume (Biava et al., 2006) and bronchial collapse during bronchoalveolar lavage (Koblinger et al., 2014). BAL analysis is more reliable than the tracheal aspirate, especially for the diagnosis of inflammatory diseases in the lower airways (De Brauwer et al., 2000). Besides, BAL technique advantages include a simpler and less aggressive procedure to the respiratory tract (Rosell et al., 2006). The passage of the endoscope to perform the BAL allows the visualization of the tracheal and bronchial lumen, and additionally, respiratory secretions that might be present (Biava et al., 2006; Murakami et al., 2012). Although BAL may be the sample of choice for disease of lower respiratory airways, the technique in wildlife animals is particularly challenging due to anatomical differences in such species, when compared to domestic animals (Biava et al., 2007).

Therefore, this study describes the first time a bronchoalveolar lavage technique was used in tapirs with clinical signs of tuberculosis in Zoo of Curitiba, Paraná, Brazil.

\section{MATERIALS AND METHODS}

Two tapirs, one male and one female from the Curitiba/PR zoo were used to evaluate the BAL technique in wildlife animals. After chemical and physical restraint of the animals (azaperone, $160 \mathrm{mg}$, more medetomidine hydrochloride, $1 \mathrm{mg}$ IM for the first animal and azaperone, 160mg, more medetomidine hydrochloride, $2 \mathrm{mg}$, IM for second), the endoscope was passed and the visual inspection of the pharynx, larynx, trachea, and bronchi was performed. Before the BAL, two $60 \mathrm{~mL}$ syringes with $0.9 \%$ saline solution, and a $20 \mathrm{~mL}$ syringe with hydrochloride lidocaine $2 \%$ were prepared. The flexible endoscope (colonoscope CF 140L, Olympus Company, USA) was passed through the nostril into the pharynx and trachea. The tracheal lumen was observed regarding the presence and quantity of secretions. The endoscope was, then, directed into the main bronchus until the lower bronchi. To reduce the cough reflex and promote local analgesia, $20 \mathrm{~mL}$ lidocaine hydrochloride $2 \%$ was inoculed. After endoscope impact in a bronchial branch it was introduced, by catheter, up to $60 \mathrm{~mL}$ of saline solution through the canal work. 
This volume was split up to minimize the pressure in the alveoli. The liquid was introduced and quickly removed by suction with a disposable syringe of $60 \mathrm{~mL}$, which is identified. The aspirate fluid was considered suitable when the color or consistency changed, which is usually a whitish, bubbly, and odorless liquid. Less than $30 \%$ of volume originally infused was recovered. After the sample aspiration the syringe was decoupled from the probe and placed in a Styrofoam box with ice, keeping at temperatures between 0 to $4^{\circ} \mathrm{C}$, and referred immediately to the laboratory. Samples were submitted prior to centrifugation and cell pellets formed were ressuspended and subjected to cytocentrifugation (Revan Citocentrífuga 2000 D). Other samples were placed in ice and taken to the Marcos Enrietti Center of Diagnosis (CDME) and Central Laboratory of Paraná State (Lacen-PR) and submitted to culture, bacilloscopy and polymerase chain reactian (PCR).

\section{RESULTS}

The bronchoalveolar lavage technique in the tapirs was quick and non-invasive. It was performed in less than five minutes. Using the airway endoscopy, mucopurulent secretions in the upper and lower respiratory tract was observed, including all the extension of the trachea, edema and hyperemia of the carina. A large amount of purulent secretion was expelled by coughing in both animals after endoscopy. The total cell count was obtained using Neubauer's chamber and cell viability was assessed by Papanicolaou and periodic acidSchiff (PAS) methods contained high quantity of inflammatory cells on light microscopy (macrophages 27,5\%, lymphocytes 0,5\%, neutrophis $67 \%$ and eosinophis 5\%). No complications were recorded and the Ziehl Nielsen stain reveled bacteria compatibility with Mycobacterium sp. Bacilloscopy, moreover PCR were performed directly from BAL and resulted negative for both animals. All bacterial culture was negative, after 40 days of incubation, and presented excessive bacterial contamination. PCR in this culture sample showed positive results for $M$. tuberculosis complex and also for Mycobacterium tuberculosis, with amplicon of predicted size. After the BAL, animals recovered from the anesthesia and could return to their stables.

\section{DISCUSSION}

The great advantage of using BAL in tapirs were the diagnosed the Mycobacterium tuberculosis infection "in vivo", without euthanasia or postmortem culture. In many different researches, the tapirs were diagnosed with Mycobacterium tuberculosis by post mortem culture and all animals were euthanatized (Sternberg et al., 2002, Michel et al., 2003). The visualization of anatomical structures and of the procedure were another important factor, because it was possible to estimate the amount of secretion along the airways with endoscopy. The tapirs showed fast breathing and respiratory dyspnea whereas its airways presented a big amount of secretion. The mucus amount in the trachea might be related to inflammatory processes as discussed by Biava et al. (2006). The present research described, for the first time, the BAL technique in tapirs, and the results demonstrated that it was a quick technique with minimal discomfort to the animals. However, the tapirs should be properly sedated for adequate endoscopy procedure through the trachea and bronchia with minimum movement. The material collected can be of high quality for cytological evaluation and it was possible to visualize and identify the type of cells, including Mycobacterium sp. after special staining, the causative agent of tuberculosis in these animals.

The mucopurulent secretion found in the airways of both animals revealed an active inflammatory process, resulting from tuberculosis, and was confirmed by the presence of increased neutrophils in the BAL. Probably the tapirs followed the same cell proportion in the BAL in comparison to other animals, with predominance of macrophages on the other cell types (Biava et al., 2006). The negative PCR results obtained from BAL samples were probably caused by inflammatory cells and bacterial contamination. M. tuberculosis, in animals raised in zoos, is known to be caused by human infection and, for that reason, employees must be screened for the disease. Infected animals may serve as reservoirs and, associated to environmental contamination, may frustrate effective disinfection. Therefore, specific identification of $M$. tuberculosis in these two tapirs is very important for zoonosis and public health since they may be a source of infection to other animals, employees and visitors while sharing common areas, particularly 
immuno-compromised individuals such as children and elders.

\section{CONCLUSIONS}

To the author's knowledge, this is the first time that bronchoalveolar lavage with endoscopic was performed in tapirs, which was crucial for definition and in vivo diagnosis of Mycobacterium tuberculosis infection. Our findings may contribute to more appropriated sampling for improving public and animal health.

\section{REFERENCES}

ANDREASEN, C.B. Bronchoalveolar lavage. Vet. Clin. Small Anim. Pract., v.33, p.69-88, 2003.

BIAVA, J.S.; GONÇALVES, R.C.; DONRBUSCH, P.T. et al. Avaliação clínica e citológica do trato respiratório de cavalos Quarto de Milha após exercício. Archs. Vet. Sci., v.11, p.60-65, 2006.

BIAVA, J.S.; GONÇALVES, R.C.M.; JAVOROUSKI, M.L.; BONAT, M. et al. Broncoalveolar lavage (BAL) technique in two Tapirs (Tapirus terrestris) for diagnosis of tuberculosis. In: CONGRESSO "TODOS PELA CONSERVAÇÃO”, 1., 2007, São Paulo. Anais... São Paulo: [s.n] 2007. p.53. (Resumo).

DE BRAUWER, E.I.; DRENT, M.; MULDER, P.G. et al. Differential cell analysis of cytocentrifuged bronchoalveolar fluid samples affected by the area counted. Anal. Quant. Cytol. Histol., v.22, p.143-149, 2000.

ESPIE, I.W.; HLOKWE, T.M.; PITTIUS, G.V. et al. Pulmonary infection due to Mycobacterium bovis in a black rhinoceros (Diceros bicornis minor) in South Africa. J. Wild Dis., v.45, p.1187-1193, 2009.
HERNÁNDEZ-DIVERS, S.; QUSE, V.; MAY, J.A. et al. Manual de Medicina Veterinária de Antas em Campo. IUCN/SSC Tapir Specialist Group (TSG), Comitê de Veterinária, 2007. Available from: < http:///www.tapirs.org/ Downloads/standards/TSG-tapirs-vet-manualport.pdf>. Accessed: may 23. 2007.

KOBLINGER, K.; HECKER, K.; NICOL, J.; et al. Bronchial collapse during bronchoalveolar lavave in horses is an indicator of lung inflammation. Equine Vet J., v.46, p.50-55, 2014.

MICHEL, A.L.; VENTER, L.; ESPIE, I.W.; COETZEE, M.L. Mycobacterium tuberculosis infections in eight species at the National Zoological Gardens of South Africa, 1991-2001. J. Zoo Wildl. Med., v.34, p.364-370, 2003.

MURAKAMI, P.S.; HO, J.; GILSON, A. et al. DETECTION OF RD RIO Mycobacterium tuberculosis in Tapirs (Tapirus terrestris) from brazilian Zoo. J. Zoo Wildl. Med., v.43, p.872875, 2012.

MURAKAMI, P.S.; JAVOROUSKI, M.L.; BONAT, M. et al. Molecular diagnosis of Mycobacterium tuberculosis in Tapirs (Tapirus terrestris) from the Curitiba Zoo, Paraná. In: CONGRESSO "TODOS PELA CONSERVAÇÃO”, 1., 2007, São Paulo. Anais... São Paulo: [s. n] 2007. p.2. (Resumo).

ROSELL, A.; XAUBET, A.; AGUSTI. C. et al. A new BAL fluid instillation and aspiration technique: A multicenter randomized study. Respirator Med., v.100, p.529-535, 2006.

STERNBERG, S.; BERNODT, K.; HOLMSTROM, A.; ROKEN, B. Survey of tuberculin testing in Swedish Zoos. J. Zoo Wildl. Med., v.33, p.378380, 2002. 